\title{
PENGARUH MOTIVASI BELAJAR MATEMATIKA TERHADAP HASIL BELAJAR SISWA ANAK BERKEBUTUHAN KHUSUS
}

\author{
${ }^{1)}$ Bhakti Nurislami ${ }^{2)}$ Naning Sutriningsih, ${ }^{3)}$ Suminto \\ Universitas Muhammadiyah Pringsewu \\ ${ }^{1)}$ bhaktinurislami4@gmail.com, 2 ) \\ naningsutriningsih@umpri.ac.id, ${ }^{3)}$ suminto@umpri_ac.id.
}

\begin{abstract}
The problem in this study is the mathematics learning outcomes of students in class VIII SLB Negeri 1 Pringsewu is low. One of the factors that is suspected to be the cause of the low student learning outcomes is the lack of student motivation. The purpose of this study was to determine whether there is an influence of mathematics learning motivation on learning outcomes of ABK students (Children with Special Needs) class VIII SLB $N 1$ Pringsewu. The population in this study were all ABK students (Children with Special Needs) class VIII SLB $N 1$ Pringsewu. The sample in this study were 17 students selected using saturated sampling techniques. Based on the analysis of the results of the study showed that there is a positive influence between the motivation to learn mathematics with the learning outcomes of ABK students (Children with Special Needs) class VIII SLB $N 1$ Pringsewu. This can be seen from the contribution of mathematics learning motivation to student learning outcomes by $16.26 \%$.
\end{abstract}

Keywords: learning motivation, mathematics learning outcomes, survey methods

\begin{abstract}
Abstrak
Masalah dalam penelitian ini adalah hasil belajar matematika siswa kelas VIII SLB Negeri 1 Pringsewu rendah. Salah satu faktor yang diduga sebagai penyebab rendahnya hasil belajar siswa adalah motivasi belajar siswa yang kurang. Tujuan penelitian ini untuk mengetahui apakah ada pengaruh motivasi belajar matematika terhadap hasil belajar siswa ABK (Anak Berkebutuhan Khusus) kelas VIII SLB N 1 Pringsewu. Populasi dalam penelitian ini adalah semua siswa ABK (Anak Berkebutuhan Khusus) kelas VIII SLB N 1 Pringsewu. Sampel dalam penelitian ini sebanyak 17 siswa yang dipilih dengan menggunakan teknik sampling jenuh. Berdasarkan analisis hasil penelitian menunjukkan bahwa terdapat pengaruh yang positif antara motivasi belajar matematika dengan hasil belajar siswa ABK (Anak Berkebutuhan Khusus) kelas VIII SLB N 1 Pringsewu. Hal ini terlihat dari besarnya kontribusi motivasi belajar matematika terhadap hasil belajar siswa sebesar 16,26\%.
\end{abstract}

\section{Kata kunci: Motivasi Belajar, Hasil Belajar Matematika, Metode Survey}

\section{PENDAHULUAN}

Anak Berkebutuhan Khusus (ABK) merupakan istilah lain untuk menggantikan kata "Anak Luar Biasa (ALB)" yang menandakan adanya kelainan khusus. Anak berkebutuhan khusus mempunyai karakteristik yang berbeda antara satu dengan yang lainnya. (Delphi. Bandhi, 2018: 1-2). Anak Berkebutuhan Khusus $(\mathrm{ABK})$ merupakan anak yang mempunyai karakteristik yang berbeda antara satu dengan yang lainnya, mereka mengalami hambatan dalam pertumbuhan dan perkembangannya. Anak yang 
dikategorikan memiliki kelainan dalam aspek fisik meliputi kelainan indra penglihatan (tunanetra), kelainan indra pendengaran (tunarungu), kelainan kemampuan berbicara (tunawicara), dan kelainan fungsi anggota tubuh (tunadaksa). Anak yang memiliki kelainan dalam aspek mental meliputi anak yang memiliki kemampuan mental lebih yang dikenal sebagai anak berbakat atau anak unggul, dan anak yang memiliki kemampuan sangat rendah yang dikenal sebagai anak tunagrahita. Anak tersebut termasuk kedalam anak berkebutuhan khusus dan mendapatkan pendidikan secara khusus.

Berdasarkan hasil wawancara dengan guru matematika SLB Negeri 1 Pringsewu yang dilaksanakan pada hari Selasa dan Sabtu tanggal 19 dan 23 Februari 2019 diperoleh keterangan bahwa anak berkebutuhan khusus Tunagrahita ringan yang berjumlah 7 orang siswa, terdapat juga anak tunarungu yang berjumlah 6 orang siswa, dan juga anak tunanetra yang berjumlah 4 orang siswa. Beliau memaparkan dari ke 17 anak berkebutuhan khusus tersebut terdapat 7 siswa yang pintar, dan 10 siswa mengalami hambatan dalam mengikuti pelajaran dikelas, kesepuluh siswa tersebut harus dituntun dalam menulis dan mengerjakan soal- soal matematika.
Dari hasil pengamatan diperoleh bahwa hasil belajar matematika siswa kelas VIII SLB Negeri 1 Pringsewu masih rendah atau kurang dari KKM yang ditetapkan yakni 60 sedangkan dari 17 siswa terdapat 7 siswa (40,3\%) yang tuntas dan 10 siswa $(59,7 \%)$ belum tuntas. Menurut Nana Sujana (2008) hasil belajar adalah "Hasil penilaian terhadap kemampuan siswa yang ditentukan dalam bentuk angka, adalah hasil penilaian terhadap kemampuan siswa setelah menjalani proses pembelajaran". Sementara menurut Jumarniati, (2016) hasil belajar adalah "Penilaian hasil usaha kegiatan belajar yang dinyatakan dalam bentuk simbol, angka, huruf maupun kalimat yang dapat mencerminkan hasil yang sudah dicapai oleh setiap siswa dalam periode tertentu".

Begitu juga pada anak tunanetra dan tunarungu didalam kelas juga harus dituntun proses belajarnya. Namun kenyataan yang ada begitu berbeda, sebagian siswa menganggap bahwa matematika adalah pelajaran yang sulit, dan siswa kurang termotivasi mengikuti pelajaran matematika. Sedangkan pada anak tunarungu siswa tersebut sulit untuk menghitung angka-angka dan soal-soal yang berbentuk cerita. Siswa tunarungu memiliki keterbatasan dalam hal mendengar dikarenakan tidak berfungsinya organ-organ pendengaran, mereka tidak mampu memahami bentuk komunikasi 
audio dari lingkungan sekitarnya (Ari Suningsih, 2017) Kebiasaan siswa yang hanya menjadi pendengar dan bersikap cuek membuatnya kurang mengembangkan kemampuan berpikir dan keaktifannya.

Keterbatasan intelegensi yang dimiliki oleh anak berkebutuhan khusus tersebut bisa dilihat pada kemampuan belajar matematika siswa yang sangat kurang, dan motivasi yang diberikan guru belum bisa mendorong siswa untuk belajar matematika. Hasrat dan keinginan berhasil dalam belajar matematika membuat siswa bersikap pasif selama pembelajaran matematika berlangsung, kurang disiplin, tidak tepat waktu, kurang aktif, namun diluar kelas atau saat pembelajaran lain siswa terlihat aktif. Hal ini terbukti dari sikap siswa selama mengikuti kegiatan pembelajaran matematika yaitu siswa cenderung diam dan menjadi pendengar saja, siswa juga malas dalam mengerjakan catatan, latihan atau pekerjaan rumah.

Dorongan dan kebutuhan belajar nya juga kurang, hal ini terlihat pada saat mengikuti pelajaran matematika siswa sering keluar kelas dengan alasan ingin kekamar mandi walau pada mata pelajaran sebelumnya siswa sudah meminta izin untuk kekamar mandi.

Banyak siswa yang masih bingung dengan harapan dan cita-cita yang dimiliki nya, siswa tidak menunjukan adanya sikap antusias siswa untuk bisa belajar matematika siswa cenderung kurang memperhatikan guru ketika menerangkan pelajaran, sehingga kurang penguasaan terhadap materi pelajaran. Cita - cita merupakan salah satu faktor yang mempengaruhi motivasi belajar. Hal ini dapat diamati dari banyaknya kenyataan, bahwa motivasi seorang pelajar menjadi begitu tinggi ketika ia sebelumnya sudah memiliki cita-cita. Implikasinya terlihat dalam proses pembelajaran, misalnya seseorang yang memiliki cita-cita menjadi guru, maka akan terlihat motivasi yang begitu kuat untuk sungguh-sungguh belajar. Hal tersebut merupakan indikator kurangnya motivasi belajar.

Ada banyak faktor yang mempengaruhi hasil belajar yang ingin dicapai oleh siswa. Salah satu faktor tersebut adalah motivasi belajar siswa. Kondisi nyata yang terjadi di SLB Negeri 1 Pringsewu mengindikasikan bahwa Rendahnya hasil belajar matematika siswa diduga dipengaruhi oleh motivasi belajar siswa yang belum tercukupi. Motivasi belajar adalah proses yang memberikan semangat belajar, arah dan kegigihan prilaku terhadap mata pelajaran. Sardiman (2012:73) mengemukakan bahwa motivasi adalah perubahan energi dalam diri seseorang yang ditandai dengan munculnya feeling dan didahului dengan tanggapan terhadap adanya tujuan. 
(Hamzah,2016:1) memperkuat pengertian motivasi melalui pernyataannya bahwa "Motivasi adalah kekuatan, baik dari dalam maupun dari luar yang mendorong seseorang untuk mencapai tujuan yang telah ditetapkan sebelumnya". Kedua pernyataan tersebut menunjukkan bahwa motivasi dapat meningkatkan, memperkuat, dan mengarahkan proses belajarnya sehingga diperoleh proses belajar yang efektif. Dari pemaparan hasil observasi tersebut dapat disimpulkan bahwa siswasiswi SLB N 1 Pringsewu masih kurang dorongan dan semangat untuk belajar yaitu motivasi.

\section{METODE PENELITIAN}

Ditinjau dari permasalahan yang ada, peneliti menggunakan pendekatan kuantitatif dengan metode korelasi yaitu penelitian sebab akibat yang tujuannya untuk mengetahui hubungan dan pengaruh antara variabel bebas dan terikat. Penelitian korelasi dibangun menggunakan teori yang telah matang, yang fungsinya untuk mengetahui, mengontrol dan menduga sebuah fenomena tertentu. Peneliti menggunakan kuisioner berupa angket yang telah divalidasi oleh peneliti sebelumnya. Data yang diperoleh berupa jawaban dari siswa terhadap pertanyaan atau butir - butir pertanyaan yang telah diajukan. Jenis penelitian ini untuk menguji ada pengaruh motivasi belajar $(\mathrm{X})$ terhadap hasil belajar (Y).

Penelitian ini berlokasi di SLB Negeri Pringsewu, Jl. Makam KH.Gholib Pringsewu, Kecamatan Pringsewu Barat, Kabupaten Pringsewu, Provinsi Lampung. SLB Negeri Pringsewu terdiri dari tiga jenjang yaitu SD, SMP, dan SMA. Pada penelitian ini peneliti hanya akan melakukan penelitian pada jenjang SMP, yang akan diteliti adalah siswa kelas VIII yang berjumlah 17 orang siswa yaitu 7 siswa Tunagrahita ringan, 4 siswa Tunanetra dan 6 siswa Tunarungu. Penelitian ini dilakukan pada semester ganjil tahun ajaran 2019-2020.

Populasi adalah jumlah keseluruhan dari satuan-satuan atau individu-individu yang karakteristiknya hendak diteliti, dan satuan-satuan tersebut dinamakan unit analisis, yang dapat berupa orang-orang, institusi-institusi, benda-benda, fenomena alam dan sebagainya.Maka dalam penelitian ini populasinya adalah seluruh siswa-siswi ABK kelas VIII SLB Negeri 1 Pringsewu yang jumlah keseluruhannya adalah 17 siswa dari 3 kelas yang terdiri dari kelas tunagrahita, tunarungu dan tunanetra

Sampel dalam penelitian ini adalah siswa kelas VIII C SLB Negeri 1 Pringsewu dengan teknik sampling jenuh, 
yaitu seluruh anggota populasi digunakan sebagai sampel. Kelas yang terpilih sebagai subjek dalam penelitian ini adalah 7 siswa Tunagrahita ringan, 4 siswa Tunanetra dan 6 siswa Tunarungu kelas VIII SLB Negeri 1 Pringsewu dengan jumlah siswa 17 orang.

\section{HASIL DAN PEMBAHASAN}

Berdasarkan hasil analisis data, dapat diketahui bahwa hasil belajar siswa rendah dipengaruhi oleh motivasi belajar. Untuk mengetahui pengaruh motivasi belajar terhadaphasil belajar siswa $\mathrm{ABK}$ menggunakan analisis regresi sederhana. Regresi sederhana digunakan untuk mengetahui pengaruh motivasi belajar terhadap hasil belajar siswa $\mathrm{ABK}$, dengan menggunakan dua uji yaitu uji linieritas dan uji korelasi. Pengaruh motivasi belajar terhadap hasil belajar siswa ABK kelas VIII SLB N 1 Pringsewu dapat dilihat dari persamaan regresi yaitu $\hat{Y}=42,77+$ $0,17 x_{i}$ yang artinya jika skor motivasi belajar meningkat satu, maka dapat meningkatkan hasil belajar siswa sebesar 0,17. Kemudian dilakukan uji regresi linier sederhana dan diperoleh hasil analisis $F_{\text {hitung }}=22,27 \quad$ yang selanjutnya dibandingkan dengan $F_{\text {tabel }}$ untuk $a=$ 0,05 dengan $\mathrm{dk}=1 \mathrm{dan} \mathrm{dk}$ penyebut $(d k=17-2=15) \quad$ didapat $F_{\text {tabel }}=$ 4,54. Dengan kriteria uji jika $F_{\text {hitung }}>$
$F_{\text {tabel }}$ maka tolak $H_{0}$. Jika $F_{\text {hitung }} \leq$ $F_{\text {tabel }}$ maka terima $H_{0}$. Karena $F_{\text {hitung }}>$ $F_{\text {tabel }}$ maka terima $H_{1}$. Jadi dapat disimpulkan bahwa ada pengaruh motivasi belajar matematika terhadap hasil belajar siswa ABK SLB N 1 Pringsewu Lampung hal ini sesuai dengan hipotesis peneliti.

Setelah analisis regresi, kemudian dilanjutkan dengan analisis korelasi. Analisis tersebut dilakukan untuk mengetahui besarnya pengaruh variabel bebas terhadap variabel terikat. Besarnya pengaruh dapat dilihat dari koefisien determinasi yaitu $(4,033)^{2} \times 100 \%=$ $16,26 \%$ artinya hasil belajar dipengaruhi oleh motivasi belajar dan sisanya dipengaruhi variabel lain. Hal tersebut juga mengandung arti bahwa motivasi belajar memiiki pengaruh terhadap hasil belajar siswa. Artinya semakin baik motivasi belajar maka hasil belajar yang didapat akan semakin tinggi. Sebaliknya semakin buruk motivasi belajar hasil belajar siswa semakin rendah.

Menurut Hamzah (2017:24) salah satu faktor yang mempengaruhi hasil belajar adalah motivasi belajar. Motivasi belajar terkait dengan pengaruh yang besar dalam kegiatan belajar siswa, khususnya terhadap hasil belajar siswa karena motivasi merupakan dasar awal yang akan membawa siswa pada perilaku belajar yang aktif serta hasil belajar yang maksimal. 
Berdasarkan hasil angket motivasi belajar yang lebih banyak mempengaruhi keegiatan belajar ialah hasrat, keinginan dan dorongan dalam belajar akan membuat siswa mencari dan menemukan suatu pengetahuan dan pengalaman-pengalaman baru. Penghargaan dan penghormatan atas diri siswa juga menjadi alas an timbulnya motivasi siswa dalam melakukan suatu kegiatan pembelajaran, sedangkan lingkungan yang baik dan kegiatan belajar yang menarik juga akan memperkuat semangat siswa dalam proses pembelajaran yang baru sehingga akan terwujud suatu pembelajaran yang aktif dan efektif. Untuk mewujudkan dua hal tersebut, guru diharapkan untuk kreatif dalam membangkitkan motivasi belajar siswa.

Siswa yang mencapai indikator hasrat dan keinginan berhasil sebesar 3,53\% (lampiran 11). Hal ini menunjukan hasrat dan keinginan berhasil memberikan sumbangan tertinggi pertama dengan pengaruh motivasi belajar terhadap hasil belajar siswa, jika siswa memiliki hasrat dan keinginan berhasil maka siswa akan mencapai hal itu dengan baik dan tentunya akan mencapai hasil yang optimal. Tetapi jika siswa tidak memiliki hasrat dan keinginan untuk berhasil maka siswa tersebut akan merasa malas dan kurang motivasi untuk belajar sehingga tidak mendapatkan hasil yang optimal.
Siswa yang mencapai indikator adanya penghargaan dalam belajar sebesar 0,372\% (lampiran 11). Hal ini menunjukkan penghargaan dalam belajar memberikan sumbangan tertinggi kedua dalam pengaruh motivasi belajar terhadap hasil belajar siswa ABK. Siswa ABK sangat perlu diberikan penghargaan dalam belajar seperti " bagus", "hebat" dan lain-lain, hal ini dapat membantu merangsang siswa dan menyenangkan siswa, pernyataan tersebut juga dapat mengandung makna interaksi dan pengalaman pribadi yang langsung antara siswa dan guru, dan dapat menambah semangat siswa untuk belajar. Menurut Sigit, E. (2014: 3) penghargaan dalam belajar dapat menumbuhkan rasa percaya diri siswa sehingga siswa akan merasa tertantang dan terlatih untuk berani bertanya dan merupakan cara paling efektif untuk meningkatkan motif belajar anak didik kepada hasil belajar yang lebih baik.

Siswa yang mencapai indikator adanya kegiatan menarik dalam belajar sebesar 0,108\% (lampiran 11).Hal ini menunjukkan kegiatan yang menarik dalam belajar memberikan sumbangan tertinggi ketiga dalam pengaruh motivasi belajar terhadap hasil belajar siswa ABK. Kegiatan belajar yang menarik dapat membantu siswa untuk memahami materi dengan efektif, baik itu dari segi simulasi maupun permainan merupakan salah satu proses yang sangat membantu bagi siswa ABK. Hal ini sesuai 
dengan pendapat Hamzah (2017: 24) bahwa suasana yang menarik menyebabkan proses belajar menjadi bermakna dan selalu diingat, dipahami, dan dihargai.

Siswa yang mencapai indikator adanya harapan dan cita- cita masa depan sebesar 0,65\% (lampiran 11). Hal ini menunjukkan bahwa harapan dan cita-cita masa depan memberikan sumbangan tertinggi keempat dalam pengaruh motivasi belajar terhadap hasil belajar siswa ABK. Menurut Hamzah (2017:25) harapan dan cita-cita masa depan didasari pada keyakinan bahwa orang yang dipengaruhi oleh perasaan mereka tentang gambaran hasil tindakan mereka contohnya siswa $\mathrm{ABK}$ yang menginginkan kenaikan nilai yang tinggi akan menunjukkan cara belajar yang baik dan memiliki mimpi serta target belajar yang sesuai, sehingga harapan dan target tersebut akan mempengaruhi hasil belajar yang tinggi. Siswa yang mencapai indikator lingkungan belajar yang kondusif sebesar 0,0672\% (lampiran 11). Hal ini menunjukan bahwa lingkungan belajar yang kondusif memberikan sumbangan tertinggi kelima dalam pengaruh motivasi belajar terhadap hasil belajar siswa ABK. Pada umumnya motif dasar yang bersifat pribadi muncul dalam tindakan individu setelah dibentuk oleh lingkungan. Oleh karena itu motif individu untuk melakukan sesuatu misalnya untuk belajar dengan baik, dapat dikembangkan, diperbaiki, atau diubah melalui belajar dan latihan, dengan perkataan lain melalui pengaruh lingkungan belajar yang kondusifadalah salah satu faktor pendorong belajar siswa, dengan demikian siswa mampu memperoleh bantuan yang tepat dalam mengatasi kesulitan atau masalah dalam belajar sehingga bisa meningkatkan hasil belajar.

Siswa yang mencapai indikator adanya dorongan dan kebutuhan dalam belajar sebesar 0,014\% (lampiran 11). Hal ini menunjukan bahwa dorongan dan kebutuhan dalam belajar memberikan sumbangan tertinggi keenam atau terakhir dalam pengaruh motivasi belajar terhadap hasil belajar siswa ABK. Dorongan dan kebutuhan dalam belajar sangat penting diberikan kepada siswa berkebutuhan khusus, siswa mungkin akan belajar dengan tekun dan menyelesaikan tugasnya dengan baik maka dia akan mendapatkan hasil yang baik pula, dan dapat membangkitkan minat belajar siswa terhadap pelajaran matematika dikelas. Dorongan dan kebutuhan belajar dapat menjadi faktor penentu dalam mencapai tujuan belajar yang akan dicapai.

\section{SIMPULAN}

Koefesien regresi motivasi belajar matematika siswa sebesar $\widehat{Y}=42,77$ $0,17 X i$, artinya semakin tinggi motivasi belajar semakin tinggi pula hasil belajar yang didapatkan. Selanjutnya ada pengaruh 
positif dan signifikan antara motivasi belajar terhadap hasil belajar matematika siswa ABK kelas VIII SLB N 1 Pringsewu tahun ajaran 2019/2020. Hal ini ditunjukan pada perhitungan korelasi dengan besarnya kontribusi pengaruh motivasi belajar matematika terhadap hasil belajar siswa Anak Berkebutuhan Khusus (ABK) yaitu $16,26 \%$ sedangkan sisanya dipengaruhi oleh faktor lain.

\section{DAFTAR PUSTAKA}

Delphi, B. (2006). Pembelajaran Anak Tunagrahita. Bandung: Refika Aditama.

Hamzah B. Uno.(2016). Teori Motivasi Dan Pengukurannya. Jakarta: Bumi Aksara

Jumarniati， (2016)."Pengaruh Motivasi Terhadap Hasil Belajar Matematika Siswa Kelas X Sman Di Kecamatan Biringkanaya". Prosiding Seminar Nasional Vol 02 ( 1). 329-331.

Nana Sudjana.(2017). Penilaian Hasil Dan Proses Belajar Mengajar. Bandung : Remaja Rosdakarya.

Sardiman. 2011. Interaksi Dan Motivasi Belajar Mengajar. Jakarta: Raja Grafindo.

Ari Suningsih, Y. A. (2017). Komunikasi Matematis Siswa Tunarungu Melalui Model Pembelajaran Think Pair Share. Aksioma, 6(3), 375-384.

Sigit, E. (2014). “Motivasi Guru Terhadap Pembelajaran Anak Tunagrahita Mampu Didik Di Slb Negeri 2 Yogyakarta". Skripsi. Fakultas Ilmu
Keolahragaan. Yogyakarta:

Universitas Negeri Yogyakarta. 